\title{
“Filosofia de botequim": síncopa, samba, a vida e o pensamento popular de Ataulfo Alves
}

\author{
Francisco Antonio Romanelli*
}

\begin{abstract}
Resumo
A vida pobre do sambista original foi motivo de farta reflexão nas letras dos sambas. Desde Noel Rosa instaurou-se uma nova poética para as letras da canção popular, em que o questionamento sobre as vicissitudes dessa vida passou a ser um dos principais objetivos do sambista. Essa era uma forma de a cultura negra resistir à desculturação e à implantação de uma ideologia de inferioridade racial, impostas pela elite dominante, basicamente branca e de tradição europeia. As letras dos sambas eram questionadoras, polissêmicas e sarcásticas, gerando o que se denomina "pensamento sincopado", baseado no uso da síncopa e motivador de certa forma de reflexão, a que se dá o nome de "filosofia de botequim". No pensamento popular, sincopado, de Ataulfo Alves, expresso por suas canções, o presente texto vai buscar a "filosofia de botequim" em questionamentos sobre a vida, a sorte, a morte e a felicidade e seus diálogos com a poesia.
\end{abstract}

Palavras-chave: Samba. Ataulfo. Filosofia. Canção. Poesia.

\section{"Barroom Philosophy": Syncope, Samba, Life and Popular Thought of Ataulfo Alves}

\begin{abstract}
The poor existence of the original samba composers was a great source for reflection in their lyrics. Since Noel Rosa a new poetics was established for the lyrics of the popular song, in which the questioning about the vicissitudes of life became one of the main objectives of samba. This was a way for black culture to withstand the opposing pressure of deculturation and the ideology of racial inferiority imposed by the ruling elite, which was basically white and traditional European. Therefore, the lyrics of the sambas were questioning, polysemic and sarcastic, in a mood called "syncopated thinking", using syncopation and generating a reflexive form, named "barroom philosophy". In the popular thought of Ataulfo Alves, expressed in his songs, the present text will address the issues about life, luck, death and happiness and their dialogues with poetry.
\end{abstract}

Keywords: Samba. Ataulfo. Philosophy. Song. Poetry.

Recebido: $16 / 01 / 2017$

Aceito: 02/09/2017

* Universidade do Vale do Rio verde (UNINCOR). Universidade do Vale do Sapucaí (UNIVAS). Mestre em Letras e Doutorando em Ciências da Linguagem 
O mundo do samba original é fundamentalmente reflexivo. ${ }^{2}$ Questiona as agruras do cotidiano pobre e sofrido. Lembra-nos Ricardo Azevedo, que a "essência do discurso do samba" é "sua tendência a ser construído no patamar da vida diária, concreta e cotidiana, vista pelo prisma do senso comum". (AZEVEDO, 2013, p. 611). Nesse movimento, atrai, paralelamente, indagações de interesse universal: maneira típica de pronunciar-se e causar estranhamento poético transposta do universo negro e pobre para o universo branco, remediado, das "elites" e da indústria cultural.

Tal interação se deve, primordialmente, à influência significativa da síncopa característica dos ritmos negros dos povos bantu. A síncopa incorporou o corpo do sambeiro e possibilitou que a "ginga" determinasse a fala e o comportamento pessoal e coletivo do grupo social, assumindo o imaginário psicológico e criativo da época, ou, no dizer de Emma Jung, elaborando arquétipos que definiram o inconsciente coletivo naquele lugar e naquele momento (JUNG, 2006, p. 65). A materialização das angústias deu origem a uma forma de fala e de pensamento "sincopados", expressão peculiar de uma maneira polissêmica, dúbia e dialógica de compor e interpretar. Dá-se a tal forma característica de expressão, que se revela no "samba malandro", o nome de "filosofia de botequim". 3

Este trabalho mostra um vislumbre da "filosofia de botequim" no pensamento popular de Ataulfo Alves, compositor mineiro que, no mundo do samba carioca, participou da chamada "era de ouro da canção popular brasileira" e contribuiu para a formatação definitiva da fala e do pensamento "sincopados", elementos da constituição e afirmação do samba como ritmo brasileiro por excelência. Falar em ritmo acentuadamente sincopado do samba leva, inevitavelmente, a caminho do jeito gingado da malandragem carioca e, principalmente, do tradicional "malandro do samba", com suas peculiaridades e trejeitos.

As questões concernentes ao discurso tradicional da fala malandra no samba, no entanto, bem como aquelas relativas à poética característica, e ao consequente valor literário das letras de canções, é um nó ainda distante de ser desatado. Passam pelas discussões sobre se se pode equiparar, esteticamente, letras de canções e poemas; se o compositor popular pode ser chamado de poeta, quando escreve letra de canção; se o poeta pode ser chamado de compositor, quando disponibiliza seu poema para ser musicado. No que se refere ao samba, a dúvida ainda mais se agrava quando, tratando-se a poesia versejada, de modo geral, de arte de intelectuais, com bom grau de escolaridade, a grande maioria dos sambistas iniciais não era suficientemente letrada.

À parte essa discussão, faltam estudos no sentido de constatar a vinculação da síncopa à expressão generalizada (fala, trejeitos, escrita, cantos etc.) do mundo do samba. No que se refere simplesmente à poética, os estudos abrangem um leque de possibilidades infinitas, desde a rejeição absoluta da aderência poesia-letra de música até a aceitação completa do amálgama. Entre a rejeição sistemática e a plena aceitação, prevalece a demonstração de uma ampla colaboração interartes: confirma-se a poética que pauta os rumos dos estilos cancioneiros, mas não se toma letra de canção por poema, ou vice-versa, mesmo quando um poema é musicado ou uma letra é publicada isoladamente. São gêneros textuais distintos e sob a ótica de tal distinção devem ser analisados e comparados. Pelo menos, por

2 Chama-se de "mundo do Samba", com "S" maiúsculo, o modo de vida que, como mecanismo de resistência à aculturação caolha imposta pela ideologia dominante, acabou se transformando em um sistema próprio de viver e de pensar, restrito ao universo pobre dos morros e de alguns bairros próximos ao centro do Rio de Janeiro, formado principalmente pelos ex-escravos ou descendentes. Esse modo de vida se organizou em torno da tradição negra e se manifestou através de reuniões festivas, musicais, dançantes, gastronômicas, esportivas, de culto religioso, de aconselhamento, atendimento medicamentoso e convivência social. Os encontros geralmente se davam nas então chamadas "Rodas de samba" ou nos candomblés (ROMANELLI, 2015b).

3 ...que "se caracteriza por um modo de questionar, através de um discurso polissêmico, as mazelas e as agruras da existência, as questões miúdas individuais e domésticas e outras de interesse particular" enquanto indaga "questões universais, como o amor, a morte, as transformações sociais, a sorte, o dinheiro". (ROMANELLI, 2015b, p. 20). 
ora, a despeito de a recente premiação literária do compositor Bob Dylan, que foi agraciado com o mais alto reconhecimento canônico, o Nobel 2016 de Literatura, pela excelência poética de suas letras, ter assoprado as brasas da polêmica. ${ }^{4}$

Lançando um olhar sob essa discussão, Charles Perrone afirma que "muitas letras de canção poderiam figurar, sem nenhum favor, ao lado dos melhores textos poéticos contemporâneos", além de constatar que "se, independente da música, o texto de uma canção é literalmente rico, não há nenhuma razão para não se considerar seus méritos literários.” (PERRONE, 1988, p. 14-15). Sem dúvida, a poética do mundo do samba, que identifica uma maneira distintiva de pensamento e comportamento, dentre outros fatores, foi influenciada pela síncopa, singularizando-se. Dentro da poética cancioneira e pensante, a "linguagem sincopada", invenção típica brasileira pela recriação cultural da tradição rítmica negra-africana, é das mais valiosas.

O pensamento do samba é rico na "miscigenação" de falas e costumes - mundo negro, de tradição africana versus elite branca, de tradição europeia. Grupos se unem em torno de pensamentos peculiares, movidos por interesses basicamente comuns, dentro de um ambiente sociológico típico, muitas vezes criando, em termos utilizados por Bakhtin, suas próprias "ideologias do cotidiano" (BAKHTIN, 2006, p. 118). A necessidade do enfrentamento de situações comuns e de superação de condições adversas, atrai maneiras de pensar, e de se manifestar, coerentes, na maior parte das vezes bem organizadas dentro de estruturas da tradição oral.

O mundo do samba é um "campo social”, usando o conceito de Bourdieu, que estabelece vínculos relacionais agregados a princípios implícitos que se encontram "não na singularidade das naturezas ou das 'almas' -, mas nas particularidades de histórias coletivas". (BOURDIEU, 2008, p. 15. Grifos do original). A par da segregação econômica, política e social, os sambistas investem fortemente em "capital cultural" de extrema especificidade, por meio de maneiras típicas de engendrar e expressar, pela fala e pelo corpo, pensamentos típicos que agregam conhecimentos populares em torno de axiomas, ditos, ditados, provérbios, apólogos, aforismos e outras manifestações de autêntica sabedoria tradicional. Tais regras de sobrevivência e coexistência obedecem a preceitos próprios, morais e éticos que se refletem e ressoam no interesse universal, extrapolando os limites de seu espaço geográfico e dialogando com a sabedoria canônica. Indagam, por seu comportamento e sua fala, peculiares e distintivos, a vida, a morte, o tempo, a felicidade, as relações pessoais e amorosas, as razões do existir, o contato com o ambiente etc.

Renato Nunes, citando Olinto Pegoraro, pondera que qualquer fazer filosófico se baseia em três métodos, sendo o primeiro, a pesquisa e a exploração do saber dos grandes filósofos; o segundo, a "busca e contemplação de metas transcendentais" e o terceiro, "a filosofia encarada como busca de sentido ou análise da experiência humana vivida no processo histórico". (PEGORARO, apud NUNES, 2002, p. 442. Destaque nosso). Ou seja, a "apresentação das inúmeras dimensões a que o ser humano é solicitado a enfrentar em seu cotidiano". (NUNES, 2002, p. 442). O ato filosófico, no entender de Karl Jaspers surge quando o discurso é capaz de "produzir no ouvinte (ainda que de experiências filosóficas, até então, apenas inconscientes) o sobressalto que nos dá súbita compreensão daquilo a que a filosofia se refere". E acrescenta que o objetivo do "pensar filosófico é levar a uma forma de pensamento capaz de iluminar-nos interiormente e de iluminar o caminho diante de nós, permitindonos apreender o fundamento onde encontremos significado e orientação.” (JASPERS, 1976, p. 11). Independentemente do pertencimento a espaços de alta complexidade acadêmica, o ato filosófico é consequência existencial pura e simples. O discurso da arte popular é eficiente para produzir sobressalto de magnitude equivalente, provocar a descoberta e atrair o aprendizado sobre os fundamentos significantes da vida; daquela vida de carências e dificuldades que se vive no mundo do Samba, pela natural vocação a realizar-se no e acomodar-se ao mundo da sociedade e da competição globais.

4 A primeira premiação nesse nível de um cancionista. 
A arte, esse indecifrável elemento de ligação entre o mundo realizado e o mundo sonhado, modelador da tradição, por suas misteriosas propriedades de criar e interpretar mundos e o mundo, de produzir linguagem simbólica de relevante conteúdo social e individual, de arrastar, para níveis da consciência, profundos estratos do inconsciente pessoal e coletivo, interessa a todas as células sociais, criando elos indissolúveis e inquebrantáveis entre umas e outras. Além disso, é um adequado veículo de reflexão sobre a existência humana (ou desumana) que é encontrada ao rés do chão do cotidiano na vida "miúda" de tal mundo do Samba, ao desabrigo da bonança social e econômica.

A arte é uma forma de se questionar e de falar sobre o universo cotidiano que compõe o plano existencial, dele se aproximando de uma forma peculiar, através de linguagem idealizada e simbólica, enquanto a filosofia, buscando o mesmo substrato, a ele se chega através da pesquisa, da análise e da reflexão. Poder-se-ia dizer, por analogia, que arte e filosofia têm linguagens afins, ao se dirigirem ao mesmo plano da existência, mas, no expressar, se abrem como as duas portas perceptivas expostas por Alfredo Bosi, inspirado em Bachelard (BOSI, 2003, p. 44): enquanto a linguagem da arte transita pela porta dos sonhos, a filosófica o faz pela porta da cultura, da memória constituída pela tradição letrada.

Por isso, Proust enuncia: “a impressão é para o escritor o que a experimentação significa para o sábio". (PROUST, 1995, p. 189). Adiante, justifica que "somente pela arte [...] podemos sair de nós mesmos, saber o que enxerga outra pessoa desse universo que não é igual ao nosso, e cujas paisagens permaneceriam tão ignoradas de nós como as que por acaso existentes na lua." (PROUST, 1995, p. 204). Ou seja, a linguagem da arte, que bebe da seiva do cotidiano, é capaz de permitir o avanço do conhecimento sobre mundos e realidades prováveis, inclusive sobre os signos que se materializam na linguagem característica do mundo do samba. Compagnon acrescenta que "exercício de reflexão e experiência de escrita, a literatura”, em especial, mas também a arte, em geral, e, por isso, as artes populares tais como as letras de canções, "responde a um projeto de conhecimento do homem e do mundo". (COMPAGNON, 2012, p. 31). Proust vai além: "Graças à arte, em vez de ver um só mundo, o nosso, nós o vemos multiplicar-se, e dispomos de tantos mundos quantos forem os artistas originais.”. (PROUST, 1995, p. 204).

Proust invoca a persistência no tempo, séculos afora, dos "raios especiais" daqueles artistas que "rolam pelo Infinito" por meio da grandeza de sua arte. Tais "raios especiais" nos lembram a "aura" benjaminiana (BENJAMIN, 1975, p. 14), que transparece da e transcende a obra de arte. No caso especial da natureza bruta do sambista primitivo, que compunha imbuído de toda uma grande carga de saber tradicional, reforçada pela paixão centrada na resistência cultural - contra a opressão que o tentava subjugar (com pensamentos, palavras e atos, inclusive perseguições, enquanto buscava impor uma ideologia de desigualdade justificada na "inferioridade" da "raça" negra) -, há de se reconhecer, pela maior proximidade com a fonte original, uma maior presença da "aura" em suas obras e em sua fala.

Pesquisadores atuais vêm encontrando diálogos valiosos e rica intertextualidade entre os gêneros acadêmicos, principalmente literários, e os mandamentos tradicionais e populares, estes veiculados notadamente por linguagens de rituais de culto ao sagrado ou da arte. É o que se dá quando a literatura e outros ramos da arte erudita buscam, nas tradições e costumes populares, a forma da mais fiel expressão estética das classes menos favorecidas, a chamada "estética do feio", e, enriquecendo-os, dão-lhes vida e voz junto às elites intelectuais, políticas e econômicas e à coletividade de consumidores culturais.

Em todas as Américas e em muitos países da Europa e da Ásia, a escravidão, e principalmente a escravidão imposta a negros africanos, forçou os cativos a movimentos de resistência cultural, a unirem-se em grupos que tinham práticas linguísticas, de culto e de tradição análogas, criando signos e códigos de convivência e manifestação peculiares, distintos dos códigos dos opressores. No Brasil, caso bem demarcado é o que mostra os negros pós-escravidão, segregados pela elite dominante, que 
se uniram em um centro urbano, na capital da república, o Rio de Janeiro, e aí, como principal meio de resistência cultural, desenvolveram uma vida típica, em torno de um pensamento religioso, voltado para o culto aos orixás, e de uma cadência rítmica sincopada - que, tempos depois, foi decisiva na construção do gênero musical denominado "samba".

O poder do ritmo sincopado praticado nos núcleos negros, no Brasil e no Rio de Janeiro, teve decisiva influência dos negros do estrato etnolinguistico dos povos bantu (LOPES, 2011, p. 101-102, 616). Esse ritmo se prestava tanto às reuniões sociais como aos cultos religiosos, às festividades e aos encontros gastronômicos, incorporou a fala como uma das mais resistentes balizas culturais, e influenciou decisivamente o comportamento desses núcleos. A ginga característica gerou um modo próprio, amalandrado, de falar e andar, agir e lutar, em pernadas ou capoeiras. Tamanha a influência do controle do corpo pelo ritmo, que autorizou o sociólogo Muniz Sodré a denominar o samba de "o dono do corpo" (SODRÉ, 2007, p. 20-21, 67).

Por outro lado, o conjunto de hábitos agregados à vida que se desenvolveu amalgamada pelo ritmo sincopado - que aqui, para melhor ilustrar a ideia, é chamada de "mundo do Samba" - adquiriu feições peculiares no que se refere à maneira de pensar, expressar-se e lidar com mazelas do cotidiano. Não se pode esquecer que, nesse começo da formação do mundo do Samba, última década do século XIX e as três primeiras décadas do século XX, na capital federal, havia forte ideologia, impingida pela elite dominante, de inferioridade racial do negro (LUZ, 2010, p. 26; SCHWARCZ, 2015), que se materializava em severas perseguições policiais, proibição de cultos, exclusão habitacional e econômica, abandono social e discriminação racial.

Tal isolamento ideológico, somado à resistência cultural negra, deu oportunidade única ao mundo do Samba de construir um sistema peculiar de pensamento e linguagem, conservando a dependência ao balanço gingado da síncopa característica dos ritmos negros. Até o final da terceira década do século XX, havia uma cisão na própria cultura negra: de um lado, o núcleo do centro da cidade, ao redor da Praça XI de Junho (englobando Cidade Nova, Saúde, Lapa, cais do porto, Gamboa), de outro os moradores das encostas de morro (ROMANELLI, 2015, p. 172). Tal divisão, que deu oportunidade à conhecida "cidade repartida pelo samba", reafirmou ainda mais o isolamento do mundo do Samba nos morros, considerado mais próximo à fala, à tradição e à cultura negras. $\mathrm{O}$ mundo do Samba na cidade, por sua proximidade e maior contato com as classes dominantes, conseguia interagir, ainda que sob o desgaste de muitas arestas, com o mundo branco, o que não acontecia com o dos morros. Aquele, afastando-se mais da ancestralidade, diluía de maneira mais incisiva a aura de sua linguagem, de sua tradição e de sua arte.

Para que os dois mundos - o excluído, da cultura negra segregada nos morros e o dominante, da cultura branca - pudessem dialogar, entendendo-se a partir de linguagens com fundamentos filosóficos e tradicionais distintos, o acento sincopado da fala e do pensamento daquele primeiro, foi essencial, possibilitando e intermediando o contato extrafronteiras. O processo de absorção do pensamento característico do mundo do Samba pela síncopa, na canção popular e no carnaval, e a consequente intermediação com o mundo branco, representado pelos interesses políticos da época (quando se procurava estabelecer a identidade do povo brasileiro) e pela incipiente indústria cultural (início das gravações fonográficas e das transmissões radiofônicas), propiciou o encontro entre as duas culturas conflitantes no curto período de cerca de apenas dez anos. A esse fenômeno, verdadeiro "milagre" cultural, dado o tamanho estranhamento que causou, o antropólogo Hermano Vianna denominou de "o mistério do samba" (VIANNA, 2012, p. 30, 34).

O ponto de aglutinação dessa ferramenta adequada para se dar voz no mundo branco ao mundo negro se colocou no chamado "samba malandro". A linguagem malandra é uma das expressões autenticadas ao mundo do Samba, tanto nos morros como na cidade. Entre morro e asfalto, surge no bairro Estácio de Sá, um novo ritmo, e uma nova maneira de compor, híbrida, o samba batucado, 
aquele que Humberto Franceschi chamou de "samba de sambar do Estácio" e que se constituiu em um "novo código de percepção musical até então desconhecido." (FRANCESCHI, 2014, p. 109) e que adequou os signos da comunicação entre mundos branco e negro. Por ele, "numa cadência própria", puderam ser compostas e manifestadas letras "revelando intensa carga do cotidiano, de um cotidiano muito peculiar." (FRANCESCHI, 2014, p. 109). Implícito nesse novo comportamento rítmico e musical, surgiu também um novo comportamento e uma nova fala malandra, que Ismael Silva, um dos pioneiros da "nova canção", chamou de "malandragem fina" (CARVALHO, 1980, p. 61).

Partindo desse ponto, da "malandragem fina", é que o compositor e cantor Noel Rosa, do bairro de Vila Isabel, trouxe à luz uma linguagem definitiva, o moderno "samba malandro", depois de configurar a figura do próprio malandro para um tipo social e legalmente tolerável, o "folgado". A essa figura, típica do imaginário do samba carioca, atribui-se o dom da fala, a linguagem polissêmica e a farta dialogia, no sentido que ao termo emprestou Bakhtin (BAKHTIN, 2002, p. 85-86), capaz de traduzir as diversas nuances das mazelas do mundo segregado do Samba, dando-lhes vida e expressão no mundo erudito das elites culturais. Não é ousadia dizer que, em termos de reflexão sobre o cotidiano, esse método criativo de estabelecer diálogo com o pensamento erudito, através da canção, é uma operação de expressão bem-sucedida, já que ele "faz a significação existir como uma coisa no coração do próprio texto [...], abre para nossa experiência um novo campo ou uma nova dimensão", conforme preconiza Merleau-Ponty (1999, p. 248).

Transformando a linguagem da composição popular e propiciando a manifestação da diversidade das vozes do mundo do Samba, Noel Rosa assume a paternidade da aqui chamada "filosofia de botequim", deflagrando um processo de reflexão sobre a existência humana a partir da vida "miúda" das pessoas socialmente desafortunadas. É certo que não se pode emprestar ao pensador de botequim, que, talvez, mereça ser chamado de "penseiro", título neologístico que se lhe atribuiu Chico Buarque na canção "Pedro pedreiro", de 1965, a condição de linguista, literato ou filósofo. Não lhe cabe deduzir hipóteses, integrar-se a correntes ou construir sistemas que indaguem, mediante procedimentos apropriados, a natureza da verdade e do bem-estar coletivos. No entanto, com a autoridade que lhe confere a arte, é criador de textos de expressiva literariedade e indagadores da vida prática e, portanto, cabe-lhe contrapor às suas vicissitudes, não na contramão da literatura ou da filosofia, mas em um paralelismo harmônico. Por outro lado, dialoga incessantemente com grandes questões universais, objetos da literatura e do pensamento, e as traz para a restrição de seu universo imediato, propondo lições de vivência que são passadas à sua cultura oral. Ou seja, dá-lhes vida efetiva na crueza do laboratório que é a existência humana.

O artista, compositor popular e sambista, usa da fala malandra e de seu pensamento sincopado para denunciar as vicissitudes de seu cotidiano, enquanto faz arte e questiona. Caetano Veloso, na canção "Língua”, de 1984, composição própria, gravada por ele e Elza Soares no álbum Velô, já sintetizara: "Se você tem uma ideia incrível / é melhor fazer uma canção / Está provado que só é possível filosofar em alemão". Não é sem razão que José Miguel Wisnik diz encontrar-se, "em certas linhas da canção" popular, "um modo de sinalizar a cultura do país", o que representa "um modo de pensar - ou, se quisermos, uma das formas da riflessione brasiliana." (WISNIK, 2004, p. 215).

Neste trabalho, busca-se apontar uma amostra do conteúdo literário e reflexivo da voz do mundo do Samba, universo generalizado dos "pouco validos" e marginalizados, e manifestado pelo gênero musical samba, dentro dos padrões dúbios e polissêmicos da fala malandra atribuída a Noel Rosa (continuada por outros grandes compositores nacionais, como Ataulfo Alves e, em tempos atuais, por Chico Buarque). Toma-se, como referência, material questionador e reflexivo que se extrai das canções do mineiro Ataulfo. Assim, usando-se algumas de suas canções, pretende-se apresentar a sua poética reflexiva por meio de quatro noções que se entretecem e se inter-relacionam e, ainda, que se imiscuem no pensamento filosófico acadêmico e na literatura: a morte, a sorte, o tempo e a felicidade. 
Por serem interdependentes, muitas vezes as argumentações do texto se deslocarão de uma para outra, para uma melhor percepção da análise.

A primeira, a morte, pode ser exemplificada na canção "Quando eu morrer", autoria solo de Ataulfo Alves, gravada em 1957, pelo próprio compositor:

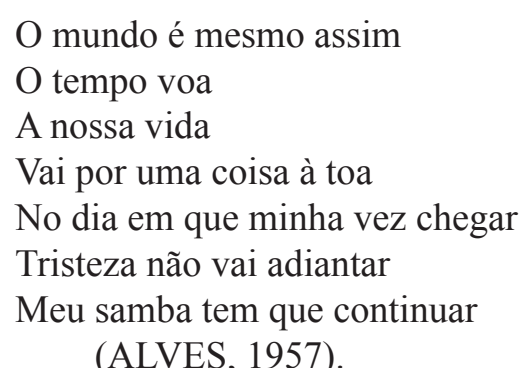

As preocupações com as transformações que constroem e desconstroem a existência, originadas em um mecanismo de impossível identificação pela ciência atual, o tempo, são lugar comum nas artes em geral, na literatura em especial e nos questionamentos filosóficos. Por isso, as questões relativas a tais esferas de pensamento se entrelaçam em muitas ocasiões. Carlos Drummond de Andrade, no poema "A morte no Avião", assim verseja a morte por acidente aeronáutico:

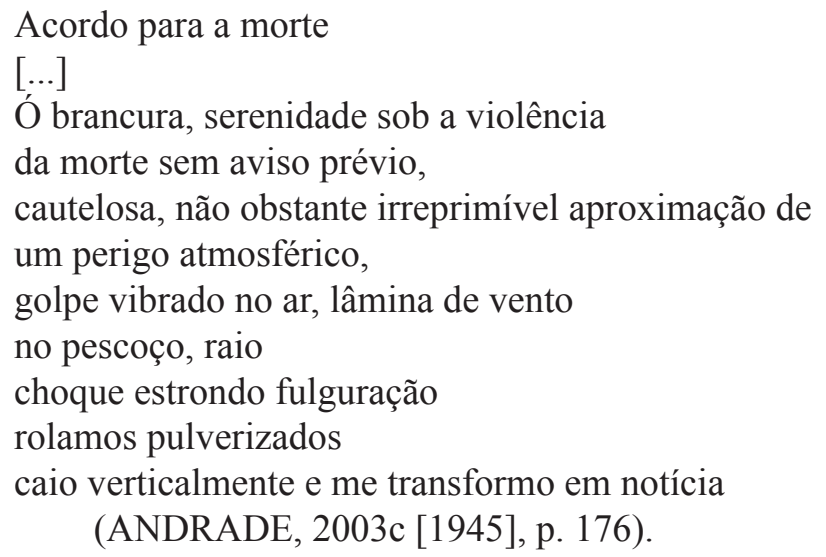

Impulsionada pelo tempo, a vida "vai por uma coisa à toa" e a hora e a vez de cada um chegam, chegam sem aviso e, por mais longa que seja a vida, sempre será breve quando oposta à morte e por ela, consumida. Sempre, "a morte chega cedo / pois breve é toda vida". (PESSOA, 1976a [1933], p. 171) $\mathrm{O}$ ser humano, calado frente à incompreensibilidade da morte, sonha com o imortal, na prole, no gene, nas palavras, nos escritos, na arte. No caso do cancionista, no samba. Na hora da morte, tristeza é inevitável, mas é inútil. "Meu samba tem que continuar". Meu samba é minha imortalidade. Assim como Clarice Lispector (na crônica "Morte de uma baleia"), o sambista indaga: "Deus, o que nos prometeis em troca de morrer? Pois o céu e o inferno nós já os conhecemos" (LISPECTOR, 1999 [1968], p. 125). O sambista sabe que a sua persistência temporal só pode teimar com a vida enquanto seu samba viver. E o lança à eternidade: o samba tem que continuar. A seu modo, comunga com o "poetinha" Vinícius (no "Soneto da Fidelidade"): se o samba não é imortal, posto que, como o amor, é chama, "que seja infinito enquanto dure" (MORAIS, 1994 [1939], p. 13). Afinal, como reconhece a rainha Gertrudes, de "Hamlet, príncipe da Dinamarca", "tudo aquilo que vive deve morrer, da Natureza passando para a eternidade". (SHAKESPEARE, 1978, p. 209). Mas, como rebate Hamlet ao encarar a inevitabilidade da morte, a "eternidade" deverá ser reservada à história, e ao nome do herói: "Horácio [...] Explica minha conduta, e justifica-me perante os olhos daqueles que duvidarem" e, adiante, "que nome desonrado ficará depois de mim se tudo permanecer assim desconhecido? [...] afasta-te algum tempo da felicidade e reserva, sofrendo, o teu sopro de vida neste mundo de dor para contar minha história" (SHAKESPEARE, 1978, p. 322). Desejo que retoma a ânsia de imortalidade 
de Aquiles, a quem à glória do nome corresponderia a morte do corpo, e a sobrevida do corpo, ao desaparecimento do nome, e optou pela eternidade do nome, em prejuízo da vida do corpo, pois era consciente de que, por mais longa que fosse, a vida teria fim: "a morte chega a quem nada faz e a quem muito alcança” (HOMERO, 2013, p. 297)5. Se morrer é inevitável e o tempo é célere e fatal, qual morte é a pior: a do corpo ou a do nome? Hoje, Aquiles teria, já há muito, morrido de qualquer forma, inda que nas vetustas idades dos pioneiros bíblicos, mas seu nome vive com vigor juvenil. Sócrates, também, mas a opção pela morte do corpo rejuvenesceu seu nome: "É a hora de irmos: eu para a morte, vós para as vossas vidas; quem terá a melhor sorte? Só os Deuses sabem" (PLATÃO, 2003, p. 30).

Ataulfo também contrapõe, no gingado de sua filosofia popular, autêntico "filósofo de botequim" que foi, a morte do homem à morte do nome, na canção "Na cadência do samba", de 1961, parceria com Paulo Gesta, gravado por Elizete Cardoso em 1962:

Sei que vou morrer, não sei o dia

Levarei saudades da Maria

Sei que vou morrer não sei a hora

Levarei saudades da Aurora

Quero morrer numa batucada de bamba

Na cadência bonita de um samba

Mas o meu nome ninguém vai jogar na lama

Diz o dito popular:

Morre o homem, fica a fama

(ALVES e GESTA, 1962)

A segunda esfera a ser examinada, ou seja, a sorte, dentre outras, pode ser vista em "Como a vida me bate", também composição solo de Ataulfo Alves e gravada pelo compositor em 1964:

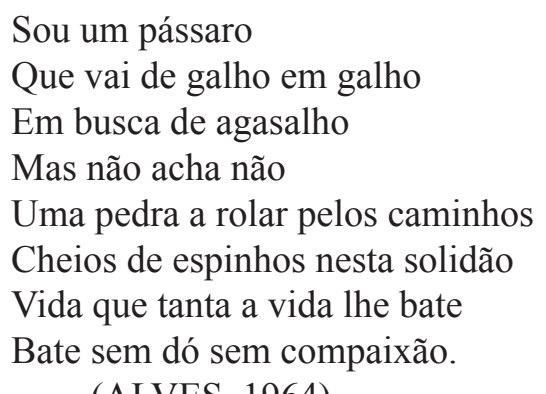

(ALVES, 1964)

Uma das perguntas mais insistentes da humanidade é aquela que questiona o sentido da vida. Importa tentar situar-se na vida. É o que o jagunço, filósofo-poeta, Riobaldo, do sertão mineiro, "matuta": "o mais importante e bonito, do mundo, é isto: que as pessoas não estão sempre iguais, ainda não foram terminadas - mas que elas vão sempre mudando. Afinam ou desafinam. Verdade maior. É o que a vida me ensinou". No entanto, a sorte, que modula a sina de cada um no correr da vida, não a faz menos arriscada. É o próprio Riobaldo que, em diversas instâncias de sua própria sorte, "o irremediável extenso da vida", reflete, se questionando: "Viver nem não é muito perigoso?" E se responde: "Viver é um descuido prosseguido"; "Viver é muito perigoso." (ROSA, 2001, p. 32, $39,45,51,86,101)$.

O compositor, na canção paradigma, faz de seu eu-poético símbolo da singeleza natural: um pássaro que, para sobreviver, "vai de galho em galho em busca de agasalho", ou "uma pedra" insignificante,

5 Canto IX, versos 320 e 410 a 416. Tétis, a mãe-deusa, o alertara da necessária escolha, mas ciente de que, para Aquiles, a vida não era a do corpo, mas a do nome, e, por isso, profetizara: "Quem dera que junto às naus estivesses sentado sem lágrimas / e sem sofrimento, visto que curta é a tua vida, sem duração! / Agora será rápido o teu destino e mais do que todos os outros / sofrerás. Para um fado cruel te dei à luz no nosso palácio" (Canto I, versos 415-418). 
“a rolar pelos caminhos", mas esbarra no dolorido existencial da alma, da razão, atributos humanos, e se queda na desilusão do musgo que, agarrado à rocha, é inerte aos açoites das ondas. Os caminhos são espinhosos e solitários e tanto a vida bate, que a ela se abandona: "bate sem dó, sem compaixão". Viver é uma prisão, ou como o príncipe Hamlet reconhece, o mundo é uma grande prisão; só lhe resta viver por uma missão: "O mundo está fora dos eixos. Oh, maldita sorte!... Por que nasci para colocá-lo em ordem!”, ainda que reconheça que a sorte é submissa ao destino: “Assim acontece com homens que possuem algum estigma vicioso por natureza [...] (trazendo a marca de um só defeito, seja devido à vestimenta da natureza, ou à roda da Fortuna)." E, conclui: "Uma partícula infinita de impureza corrompe a substância mais nobre, rebaixando-a ao nível de sua própria degradação." (SHAKESPEARE, 1978, p. 219, 227).

A terceira esfera é a do tempo. Neste texto, o tempo será vislumbrado por meio de "Fogueira do coração", canção composta por Ataulfo Alves e Torres Homem e gravada pelo primeiro compositor em 1945:

\author{
A vida é bem curta \\ Depressa ela passa \\ Por isso devemos brincar e folgar \\ O peito da gente também é fogueira \\ Que vive soltando suspiros e ais \\ A felicidade é tão passageira \\ Que quando nos deixa não quer mais voltar
}

(ALVES e HOMEM, 1945)

O tempo, esse misterioso processo que a tudo e todos conforma, transforma, desforma, deforma; traz à vida, transporta a sorte, e leva à morte. Essa insondável maquinação da natureza que ultrapassa os limites da ciência, da razão e da filosofia; essa incógnita que somente pode ser enfrentada pela arte, faz da vida uma dádiva passageira e temporária, cruelmente curta, como se reconhece na canção: "a vida é bem curta / depressa ela passa". As personagens da epopeia proustiana buscam o "Tempo perdido", perdidas elas próprias em um caminho que não pode chegar a destino algum, senão à fatalidade do desenlace promovido pela morte.

No inopino da morte que rasga o tempo que deveria se ter completado em outra magnitude, Drummond, no poema "A um ausente", se indigna à vista do morto:

Antecipaste a hora.

Teu ponteiro enlouqueceu, enlouquecendo nossas horas.

Que poderias ter feito de mais grave

do que $o$ ato sem continuação, $o$ ato em si,

o ato que não ousamos nem sabemos ousar

porque depois dele não há nada?

(ANDRADE, 2003a, p. 1406).

Chico Buarque, por seu lado, na voz do eu-poético de "Roda viva", canção por ele composta e gravada em 1967, exclama: “o tempo rodou num instante / as voltas do meu coração”. Não há controle sobre o tempo, e o tempo é célere. Curta é a vida, como lembra Jennifer Michael Hecht, citando Hamlet: “Apague, apague, vela curta” (HECHT, 2009, p. 70). Virgílio há muito já clamara: Sed fugit interea fugit irreparabile tempus. ${ }^{6}$

A canção ainda conclama: se a vida passa depressa, devemos "brincar e folgar", bem ao molde dos habitantes do mundo do samba, um mundo onde só desventuras se apresentam, e só o samba é sua 
cura. Brincar e folgar é sambar. É se entregar a esse prazer que domina e supera a dor, como se vê em "Samba da bênção", composição de Vinícius de Moraes e Baden Powell, gravada pelo "poetinha" em 1966:

É melhor ser alegre que ser triste

alegria é a melhor coisa que existe

$[\ldots]$

mas pra fazer um samba com beleza

é preciso um bocado de tristeza

senão, não se faz um samba não

$[\ldots]$

porque o samba é a tristeza que balança

e a tristeza tem sempre uma esperança

a tristeza tem sempre uma esperança

de um dia não ser mais triste não

(MORAES e POWELL, 1966).

O tempo traz a efemeridade da vida, o tempo traz o prazer e o destrói; o tempo traz a infelicidade e lhe assegura longa duração. Para afrontá-lo, ainda que episodicamente, o sambista, mesmo sabedor de que "o samba é a tristeza que balança", transforma sua tristeza na satisfação da beleza com que se faz um verdadeiro samba. E com que, nele, na composição, na execução ou na dança, se sinta pleno de prazer. Essa é a utópica esperança da tristeza, a de vencer a própria tristeza e "um dia não ser mais triste não". No entanto, como toda utopia é irrealizável, a tristeza sempre vai retomar o corpo e a alma do sambista e ser a matriz do samba feito com esmerada beleza, porta-voz do canto de alegria. Como reconhece a canção paradigma, a felicidade é tão passageira, que quando se vai, nem mesmo quer voltar, mas será incorporada a um novo samba e, pelo samba, voltará para "brincar e folgar". Como disse Quintus Horatius Flaccus (Horácio - 65 AC - 8 AC), Carpe diem, quam minimum credula postero (SANTANA, 1999, p. 59) ${ }^{7}$ : ou seja, aproveite bem o dia, porque o amanhã é incerto. Parafraseando-o (ou parodiando-o): aproveita-se o samba no instante em que se instaura, com toda alma e enquanto durar; o amanhã do pobre morador do mundo do Samba, esse sim, é absolutamente incerto e, certamente, opressivo. De tudo, apenas a certeza de que a tristeza voltará, para novamente se converter, "com beleza", no catártico efeito do samba.

Se curta é a vida, muito mais curta é a felicidade, a quarta esfera destas indagações, outro mistério da mente. De todas as perguntas que têm intrigado poetas, cientistas, psicanalistas e filósofos, uma das de maior peso é a que indaga: “o que é a felicidade?” ou “a felicidade realmente existe? Quando? Em quê?" Do eudaimon de Sócrates, revisto por Aristóteles, passando pelo conceito de potência de Spinoza, até os filósofos modernos, o espírito do bem-estar, ou da felicidade, permanece inescrutável em seu mistério, motivando as mais diversas indagações. Busca-se, na demanda da felicidade, o domínio do tempo, pois, sem o tempo, a (in)felicidade seria eterna. É, ainda, Hamlet quem o diz: "Ó Deus! Como me parecem abjetos, antiquados, vãos e inúteis todos os usos deste mundo!” (SHAKESPEARE, 1978, p. 210). Ataulfo ainda questiona os efeitos do tempo entrelaçado à felicidade (o que são? Onde estão? Para onde vão?) em uma de suas mais conhecidas canções, de raro efeito nostálgico, a melancólica e autobiográfica "Meus tempos de criança”, composição solo e gravada pelo autor em 1956:

Eu daria tudo que eu tivesse

Pra voltar aos dias de criança

Eu não sei pra quê que a gente cresce

Se não sai da gente esta lembrança

[...]

7 "Aproveita o presente e não confies / Crédula no futuro" (HORÁCIO, 1806, p. 57). Ou, "colhe cada dia, confiando o menos possível no amanhã", na tradução de Pedro Braga Falcão (HORÁCIO, 2008, p. 69). 
Eu era feliz e não sabia

(ALVES, 1956)

A canção revisita o mito da infầncia feliz. Há sempre alguma coisa, de um mundo antigo e distante, perdido, que se foi (perdoem-me o uso do lugar-comum) "nas brumas do tempo", que a carência de sentidos racionais (essa "falta" é impossível de ser saciada pela razão - Freud que o diga) tenta arrastar de um paraíso perdido para o agora. - São as saudades do paraíso celeste, da casa do Pai -, dizem os religiosos cristãos. Como essa sensação está no tempo perdido nos confins do resgate psicológico de algo de bom, que se foi, que não está mais aqui, é quase sempre buscada na infância. Há uma natural nostalgia da alegria infantil que se deixou para trás, em um tempo em que tudo era apenas felicidade, ainda que, em realidade, não o fosse. A canção paradigma é autobiográfica. Daí, muito embora autores nem sempre sejam confiáveis, principalmente no campo da arte, desconfia-se que, de fato, Ataulfo estivesse saudoso dessa infância perdida, passada na "pequenina Miraí", da Zona da Mata mineira, onde nasceu, ainda que sua vida tenha sido pobre e de muito sofrimento e dificuldades.

É o mesmo mito, travestido, que nos faz sempre refletir que "no passado, as coisas eram melhores". A arte em geral e a canção popular em particular estão recheadas de exemplos da angústia do hoje, quando se confronta o hoje ao ontem. Na literatura, que transita entre Faustos e Dorians Gray, há o exemplo típico de um lugar-comum da nostalgia, repisado na canção: "eu daria tudo que eu tivesse pra voltar aos dias de criança" (destaque nosso). Na literatura, pela juventude e pela felicidade, chegase a entregar o valor máximo que se acredita possuir: a própria alma. Para o samba, entretanto, não se chega a tanto. Basta empenhar o "tudo", como clama o eu-poético da canção. É o que, também, se vê em "Meus vinte anos" de Wilson Batista e Sílvio Caldas, gravada por este último em 1942:

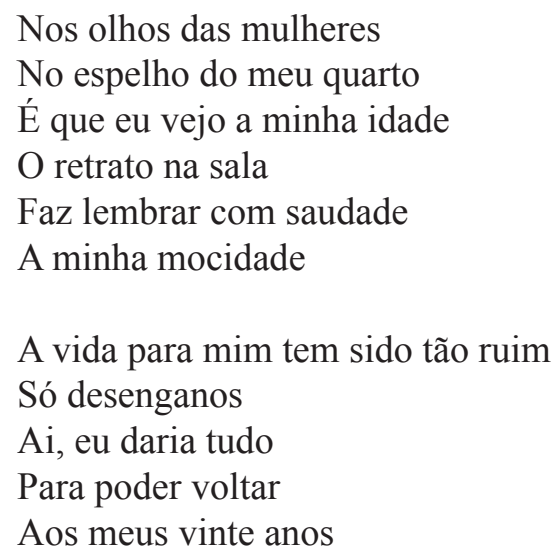

(BATISTA e CALDAS, 1942)

A volta à juventude está na conversão da esperança, que a maturidade rechaça pela certeza da morte próxima, na nostalgia, que traz a alegria de antes, mas não a instaura no agora. A dor da saudade da alegria pretensamente vivida é resgatada na experiência do agora como dor. No entanto, como já se disse: a dor é a matéria prima do samba, exemplo que também pode ser visto em "Quantas lágrimas", canção de Manacéa e gravada em 1970 pela Velha Guarda da Portela:

\footnotetext{
Ah, quantas lágrimas eu tenho derramado

Só em saber que não posso mais

Reviver o meu passado

Eu vivia cheio de esperança

E de alegria, eu cantava, eu sorria

Mas hoje em dia eu não tenho mais

A alegria dos tempos atrás

Só melancolia os meus olhos trazem
} 
Ai, quanta saudade a lembrança traz

Se houvesse retrocesso na idade

Eu não teria saudade

Da minha mocidade

(MANACÉA, 1970)

Tanto o ontem quanto o amanhã, em nossa nostalgia ou em nossa esperança, respectivamente, foram e serão melhores que hoje, à medida que continuem no passado ou no futuro. $\mathrm{O}$ agora, eterno (até que o resto seja silêncio) veículo de trânsito da vida, sempre é o pior dos momentos. Como vivemos sempre no presente, no "agora", sempre vivenciaremos os piores momentos, sonhando com a felicidade perdida no passado e a utópica esperança da que encontraremos no futuro. Jennifer Hecht lembra: "há muita coisa em nossa vida cotidiana que passa despercebida porque estamos perto demais dela. Precisamos de comparação histórica para tornar visíveis nossos próprios rituais" (HECHT, 2009, p. 15).

Clarice Lispector, na crônica "Medo do desconhecido", indaga a felicidade: "O amor pela vida mortal a assassinava docemente, aos poucos. E o que é que eu faço? Que faço da felicidade? Que faço dessa paz estranha e aguda, que já está começando a me doer como uma angústia, como um grande silêncio?” (LISPECTOR, 1999 [1967], p. 35). A conclusão é inevitável: para não doer, a felicidade tem que ser descontinuada. Ou se transforma em angústia. Ninguém consegue, em sã consciência, tolerar o gozo contínuo: ou ele é episódico e dá prazer - e, portanto, felicidade - ou ele é permanente e se transforma no ordinário, convertendo-se em angústia existencial, em tormento. Aí, o paradoxo de se ter que desejar a dor, como alívio temporário do gozo, como a escritora, na mesma obra, pela crônica "O processo", conclui: "Há um ponto em que o desespero é uma luz, e um amor" (LISPECTOR, 1999 [1967], p. 26), ou como Drummond, bem-humorado, define: "Não há felicidade que resista à continuação de tempos felizes", ou, ainda: "Quando estamos muito felizes, sentimos falta de sentir falta de alguma coisa" (ANDRADE, 2003b, p. 912, 913).

A arte sempre busca o resgate da nostalgia primordial, que se mostra no mito da infância feliz. Álvaro de Campos, um dos heterônimos de Fernando Pessoa, a explica no poema "Aniversário":

No tempo em que festejavam o dia dos meus anos,

Eu era feliz e ninguém estava morto.

Na casa antiga, até eu fazer anos era uma tradição de há séculos,

$\mathrm{E}$ a alegria de todos, e a minha, estava certa com uma religião qualquer.

No tempo em que festejavam o dia dos meus anos,

Eu tinha a grande saúde de não perceber coisa nenhuma,

De ser inteligente para entre a família,

E de não ter as esperanças que os outros tinham por mim.

Quando vim a ter esperanças, já não sabia ter esperanças.

Quando vim a olhar para a vida, perdera o sentido da vida.

(PESSOA [CAMPOS], 1976b [1929], p. 379).

O adulto de hoje, que já não sabe ter esperanças e já perdeu o sentido da vida, sempre será a criança feliz de ontem - eu era feliz porque tudo era vida e alegria; eu era essa alegria, como se isso fosse um mandamento de fé, religioso, intocável e eterno e eu tinha a saudável ingenuidade de não me dar conta de coisa alguma -. No entanto, é o próprio Fernando Pessoa, falando por si próprio, que, no poema "Pobre velha música", clama pelo resgate da infância diluída no paraíso que se perdeu:

Pobre velha música!

Não sei por que agrado,

Enche-se de lágrimas

Meu olhar parado

Recordo outro ouvir-te. 
Não sei se te ouvi

Nessa minha infância

Que me lembra em ti

Com que ânsia tão raiva

Quero aquele outrora

E eu era feliz! Não sei:

Fui-o outrora agora.

(PESSOA, 1976c [1913], p. 140-141).

A ânsia pela felicidade passada, que nem sequer sabe-se se a teve, já que o adulto que a pretende resgatar "sabe" apenas no "agora" que foi feliz "então", mas não o sabia "ainda", tem que dolorosamente ser resgatada pela memória já falha pela idade e contaminada pelo hoje (na verdade, memórias passadas não existem; o que se tem é a releitura atualizada daquilo que o cérebro apresenta como uma gravação de antanho, uma verdade de que se tem que duvidar). Na poética impecável de Pessoa, o eu-lírico reconhece: não sei se eu era feliz então, mas "fui-o outrora agora". A nostalgia do passado, do outrora me traz aquela felicidade agora; o outrora, no agora, é feliz. Não importa se, para além da nostalgia, o passado era infeliz ou se eu não tinha consciência dele ser ou não feliz. Isso traz uma indagação profunda e de difícil solução: é possível ser feliz sem o saber, no exato momento em que se vive a sensação depois resgatada pela memória como sendo de felicidade?

A vida passa, a morte é fatal, o tempo a traz; no tempo atrás, a felicidade ficou e agora se desfaz, fumaça intangível, soprada pela brisa do vento que, no tempo, a leva, para nunca mais. Guilherme de Almeida (no poema "Coração") questiona:

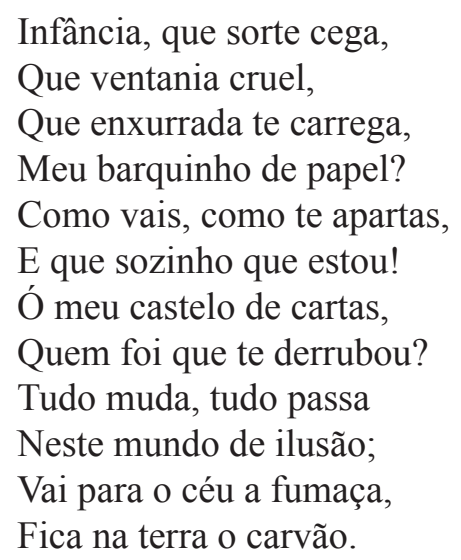

(ALMEIDA, 2010, p. 21).

A felicidade, dizem os budistas, está no desapego, mas o desapego é a morte do prazer e da dor e, portanto, inclusive da arte. E é a morte da felicidade, já que ela mesma, sendo episódica e desejada, é, portanto, puro apego. A (in)felicidade é força motriz da arte; do lodo da tristeza ou do paraíso da alegria instaura na realidade do dia-a-dia o tempo simbólico que a arte invoca. Quem puder que a entenda, no real, ou no simbólico. Drummond já disse: "Ser feliz sem motivo é a mais autêntica forma de felicidade" (ANDRADE, 2003b, p. 913). A felicidade, para o poeta, é um estado da alma, disponível a todos, a todo o tempo que, sempre que quiserem e souberem, poderão resgatá-la de dentro para fora.

Como se percebe pelo exemplo das canções citadas como paradigmas, as questões da vida, englobando a morte, a sorte e a felicidade, eram fundamentos da arte de Ataulfo Alves que, ao indagálas, lançava ao eterno movimento da filosofia e à grandiosidade criadora da arte, a vida pobre do cotidiano do sambista. Autêntica "filosofia de botequim". 


\section{Referências:}

ALMEIDA, Guilherme de. Melhores poemas. Seleção: Carlos Vogt. 3. ed. São Paulo: Global, 2010. ALVES, Ataulfo. Como a vida me bate. Intérprete: Ataulfo Alves. In: Ataulfo Alves. Na ginga do Samba. Rio de Janeiro: Philips, p1964. 1 disco sonoro, 33 1/3 rpm, mono, 12 pol. Lado B, faixa 2.

ALVES, Ataulfo. Meus tempos de criança. Intérprete: Ataulfo Alves. Rio de Janeiro: Sinter, p1956. 1 disco sonoro, 78 rpm, mono, 8 pol. Lado 1 (faixa única).

ALVES, Ataulfo. Quando eu morrer. Intérpretes: Ataulfo Alves e suas pastoras. In: Ataulfo Alves. Ataulfo Alves e suas pastoras no Clube do Samba. Rio de Janeiro: Sinter, p1957. 1 disco sonoro, 33 1/3 rpm, mono, 12 pol. Lado B, faixa 4.

ALVES, Ataulfo; GESTA, Paulo. Na cadência do Samba. Intérprete: Ataulfo Alves. In: Ataulfo Alves. Meu Samba... minha Vida. Rio de Janeiro: Philips, p1962. 1 disco sonoro, 33 1/3 rpm, mono, 12 pol. Lado A, faixa 1.

ALVES, Ataulfo; HOMEM, Torres. Fogueira do Coração. Intérprete: Ataulfo Alves. Rio de Janeiro: Odeon, p1945. 1 disco sonoro, 78rpm, mono, 8 pol. Lado 1 (faixa única).

ANDRADE, Carlos Drummond de. A um ausente. In: Poesia completa: volume único. 1. Ed. 1. Reimp. Rio de Janeiro: Nova Aguilar, 2003a. (Da obra "Farewell” [1996]).

ANDRADE, Carlos Drummond de. Felicidade. In: Prosa seleta: volume único. Rio de Janeiro: Nova Aguilar, 2003b. (Da obra "O avesso das coisas").

ANDRADE, Carlos Drummond de. Morte no avião. In: Poesia completa: volume único. 1. Ed. 1. Reimp. Rio de Janeiro: Nova Aguilar, 2003c. (Da obra “A Rosa do Povo" [1945]).

AZEVEDO, Ricardo. Abençoado \& danado do Samba: um estudo sobre o discurso popular. São Paulo: EDUSP, 2013.

BAKHTIN, Mikhail. Interação verbal. In: BAKHTIN, Mikhail. Marxismo e filosofia da linguagem. Tradução de Michel Lahud; Yara Vieira. 12. ed. São Paulo: Hucitec, 2006 (Cap. 6).

BAKHTIN, Mikhail. O discurso na poesia e o discurso no romance. In: BAKHTIN, Mikhail. Questões de literatura e de estética: a teoria do romance. Tradução de Aurora Fornoni Bernadini et al. 5. ed. São Paulo: Hicitec: Annablume, 2002 (part. 2, cap. II).

BATISTA, Wilson; CALDAS, Sílvio. Meus vinte anos. Intérprete: Sílvio Caldas. Rio de Janeiro: Victor, p1942. 1 disco sonoro, 78rpm, mono, 8 pol. Lado 2 (faixa única).

BENJAMIN, Walter. A obra de arte na época de suas técnicas de reprodução. In: Os Pensadores vol. XLVIII. Tradução de José Lino Grünnewald. São Paulo: Abril, 1975.

BOSI, Alfredo. Sobre alguns modos de ler poesia: memórias e reflexões. In: BOSI, Alfredo (Org.). Leitura de poesia. São Paulo: Ática, 2003.

BOURDIEU, Pierre. Espaço social e espaço simbólico. In Razões práticas: sobre a teoria da ação. Tradução de Mariza Correa. 9. ed. Campinas: Papirus, 2008.

CARVALHO, Luiz Fernando Medeiros de. Ismael Silva: samba e resistência. Rio de Janeiro: José Olympio, 1980.

COMPAGNON, Antoine. Literatura para quê? Tradução de Laura Taddei Brandini. 1. reimp. Belo Horizonte: UFMG, 2012.

FRANCESCHI, Humberto M. Samba de sambar do Estácio: de 1928 a 1931. 1. reimp. São Paulo: Instituto Moreira Salles, 2014.

HECHT, Jennifer Michael. O mito da felicidade: por que o que achamos que é certo é errado. São Paulo: Larousse, 2009. 
HOLlANDA, Chico Buarque de. Pedro pedreiro. Intérprete: Chico Buarque de Hollanda. In: Diversos. Paramount, templo da bossa. Rio de Janeiro: RGE, p1965. 1 disco sonoro, 33 1/3 rpm, mono, 12 pol. Lado A, faixa 3.

HOLLANDA, Chico Buarque de. Roda viva. Intérpretes: Chico Buarque de Hollanda e MPB 4. Rio de Janeiro: RGE, p1967. 1 disco sonoro, 33 1/3 rpm, mono, 8 pol., Compacto Duplo. Lado A, faixa 1. HOMERO. Ilíada. Tradução de Frederico Lourenço. São Paulo: Penguin Classics Cia. Das Letras, 2013.

HORÁCIO. Livro I, Ode 11. In: Obras de Horácio, traduzidas em verso portuguez. Tradução de José Agostinho de Macedo. Lisboa: Impressão Régia, 1806. (Disponível em <www.archive.org > Acesso em: 29 Jul. 2016).

HORÁCIO. Livro I, Ode 11. In: Odes. Tradução de Pedro Braga Falcão. Lisboa: Cotovia, 2008.

JASPERS, Karl. Introdução à Filosofia. 3. ed. Tradução de Leonidas Hegenberg; Octanny Silveira da Mota. São Paulo: Cultrix, 1976.

JUNG, Emma. Animus e anima. Tradução de Dante Pignatari. São Paulo: Cultrix, 2006. (7. a reimp., 2013).

LISPECTOR, Clarice. Medo do desconhecido. In: A descoberta do Mundo. Rio de Janeiro: Rocco, 1999 [1967].

LISPECTOR, Clarice. Morte de uma baleia. In: A descoberta do Mundo. Rio de Janeiro: Rocco, 1999 [1968].

LOPES, Nei. Enciclopédia Brasileira da Diáspora africana. 4. ed. São Paulo: Selo Negro, 2011.

LUZ, Marco Aurélio. Cultura negra e ideologia do recalque. 3. ed. Rio de Janeiro: EDUFBA; Pallas, 2010.

MACEDO, José Agostinho. Obras de Horácio traduzidas em verso Portuguez. Tomo 1. Lisboa: Impressão Régia, 1806.

MANACÉA. Quantas lágrimas. Intérpretes: Velha Guarda da Portela. In: Velha Guarda da Portela. Portela, passado de glória. Rio de Janeiro: RGE, p1970. 1 disco sonoro, 33 1/3 rpm, mono, 12 pol. Lado A, faixa 7.

MERLEAU-PONTY, Maurice. Fenomenologia da percepção. Tradução de Carlos Alberto Ribeiro de Moura. 2. ed. São Paulo: Martins Fontes, 1999.

MORAES, Vinícius de. O melhor de Vinícius de Moraes. São Paulo: Folha, 1994 [1939].

MORAES, Vinícius de; POWELL, Baden. Samba da bênção. Intérprete: Vinícius de Moraes. In: Vinícius de Moraes. Vinícius, poesia e canção. Rio de Janeiro: Forma, p1966. 1 disco sonoro, 33 1/3 rpm, mono, 12 pol. Lado A, faixa 1.

NUNES, Renato. A filosofia e o filosofar. In PIOSEVAN, Américo et al (Org.). Filosofia e ensino em debate. Ujuí: Unijuí, 2002.

PERRONE, Charles A. Letras e letras da Música Popular Brasileira. Tradução de José Luiz Paulo Machado. Rio de Janeiro: Elo, 1988.

PESSOA, Fernando [CAMPOS, Álvaro de]. Aniversário. In: Obra poética: volume único. 6. ed. Rio de Janeiro: Nova Aguilar, 1976b. (Da obra "Ficções do Interlúdio: Poesias de Álvaro de Campos" [1929]).

PESSOA, Fernando. A morte chega cedo. In: Obra poética: volume único. 6. ed. Rio de Janeiro: Nova Aguilar, 1976a. (Da obra "Cancioneiro" [1933]).

PESSOA, Fernando. Pobre velha música. In: Obra poética: volume único. 6. ed. Rio de Janeiro: Nova Aguilar, 1976c. (Da obra "Cancioneiro" [1913]). 
PLATÃO. Apologia de Sócrates. E-book. (Sem identificação de tradutor). Pará de Minas, MG: Virtualbooks Online, 2003.

PROUST, Marcel. O tempo recuperado (vol. VII de Em busca do tempo perdido). Tradução de Fernando Py. Rio de Janeiro: Ediouro, 1995.

ROMANELLI, Francisco Antonio. Rio de Janeiro: uma cidade dividida pelo samba. In BIANCHI, Leonor (Org.). Rio: 450 anos de histórias. Nova Friburgo: E-ditora, 2015.

ROMANELLI, Francisco Antonio. Roda de samba, roda da vida: filosofia de botequim em Noel, Paulinho e Chico. Varginha: Francisco Antonio Romanelli, 2015b.

ROSA, João Guimarães. Grande sertão: veredas. 19. ed. Rio de Janeiro: Nova Fronteira, 2001.

SANTANA, Ivan Justen. A tradução literária e o Polacolocopaca. Cadernos de Literatura em Tradução. n. 3. São Paulo: USP, 1999. (p. 55-64).

SCHWARCZ, Lilia Moritz. O espetáculo das raças: cientistas, instituições e questão racial no Brasil 1870-1930. 13. reimp. São Paulo: Cia. das Letras, 2015.

SELDOM, John Rose. Works of Virgil translated into English Prose. v. I. 4.ed. London (Britain): Library of Princeton University, 1794.

SHAKESPEARE, William. Hamlet, príncipe da Dinamarca. In: Shakespeare: Tragédias. Tradução de F. Carlos de Almeida Cunha Medeiros; Oscar Mendes. São Paulo: Abril Cultural, 1978.

SODRÉ, Muniz. Samba, o dono do corpo. 2. ed. 2. Reimp. Rio de Janeiro: Mauad, 2007.

VELOSO, Caetano. Língua. Intérpretes: Caetano Veloso e Elza Soares. In: Caetano Veloso. Velô. Rio de Janeiro: Polygram, p1984. 1 disco sonoro, 33 1/3 rpm, estéreo, 12 pol. Lado B, faixa 5.

VIANNA, Hermano. O mistério do samba. 2. ed. Rio de Janeiro: Zahar, 2012.

WILKINSON, L. P. The Georgics of Virgil: a critical survey. Cambridge (Britain): Cambridge University Press, 1978. Disponível em: <https://books.google.com.br $>$. Acesso em out. 2015.

WISNIK, José Miguel. Sem receita: ensaios e canções. São Paulo: Publifolha, 2004. 